\title{
p53 AND MDM2 PROTEIN EXPRESSION IN ACTINIC CHEILITIS
}

\author{
Maria da Conceição Andrade de FREITAS ${ }^{1}$, Luciana Maria Pedreira RAMALHO², Flávia Caló Aquino XAVIER ${ }^{1}$, \\ André Luis Gomes MOREIRA ${ }^{1}$, Sílvia Regina Almeida REIS ${ }^{2}$
}

1- DDS, MSc, Department of Propaedeutics and Integrated Clinic, School of Dentistry, Federal University of Bahia, Salvador, BA, Brazil.

2- DDS, MSc, PhD, Full Professor, Department of Propaedeutics and Integrated Clinic, School of Dentistry, Federal University of Bahia, Salvador, BA, Brazil.

Corresponding address: Dr. Silvia R. A. Reis, Department of Propaedeutics and Integrated Clinic, School of Dentistry, Federal University of Bahia, Av. Araújo Pinho, 62/64, 40.110-150, Salvador, BA, Brasil

Phone: +55 71 3283-9007 - Fax: +55 71 3283-8964 - e-mail: srareis@uol.com.br

Received: June 11, 2007 - Modification: January 25, 2008 - Accepted: April 17, 2008

\begin{abstract}
A ctinic cheilitis is a potentially malignant lip lesion caused by excessive and prolonged exposure to ultraviolet radiation, which can lead to histomorphological alterations indicative of abnormal cell differentiation. In this pathology, varying degrees of epithelial dysplasia may be found. There are few published studies regarding the p53 and MDM2 proteins in actinic cheilitis. Fifty-eight cases diagnosed with actinic cheilitis were histologically evaluated using Banóczy and Csiba (1976) parameters, and were subjected to immunohistochemical analysis using the streptavidin-biotin method in order to assess p53 and MDM2 protein expression. All studied cases expressed p53 proteins in basal and suprabasal layers. In the basal layer, the nuclei testing positive for p53 were stained intensely, while in the suprabasal layer, cells with slightly stained nuclei were predominant. All cases also tested positive for the MDM2 protein, but with varying degrees of nuclear expression and a predominance of slightly stained cells. A statistically significant correlation between the percentage of p53 and MDM2-positive cells was established, regardless of the degree of epithelial dysplasia. The expression of p53 and MDM2 proteins in actinic cheilitis can be an important indicator in lip carcinogenesis, regardless of the degree of epithelial dysplasia.
\end{abstract}

Key words: Cheilitis. Immunohistochemistry. p53. MDM2 protein.

\section{INTRODUCTION}

Regular and prolonged exposure to solar radiation can lead to wide-spectrum tissue alterations ranging from atrophy to dysplastic alterations in the labial mucosa, which can cause histomorphological alterations indicative of abnormalities in normal cell differentiation ${ }^{29}$. The most commonly observed alteration in the lower lip is manifested as actinic cheilitis, considered a premalignant lesion by the World Health Organization ${ }^{24}$ (1997), with the possibility of a malignant transformation in approximately 10 to $20 \%$ of the cases ${ }^{10}$.

From a histopathological point of view, actinic cheilitis is characterized by stratified squamous epithelium with ortho- or parakeratinized hyperkeratosis. Areas of acanthosis, atrophy and epithelial dysplasia can also be observed. In the region subjacent to the epithelium, chronic inflammatory infiltrates can be seen on the lamina propria with amorphous basophilic degeneration of the collagen and elastic fibers, known as solar elastosis, which is possibly a result of ultraviolet radiation ${ }^{11,19,29}$.
During normal cell development, the p53 protein, produced by the expression of the p53 gene, is not required. However, in situations of cell stress, its expression is stimulated. Therefore, when ionizing radiation, oxidative reactions, hypoxemia and the action of oncogenic proteins cause damage to DNA, p53 will be phosphorylated and activated in its wild form. If this process fails, it will act in the transcription of genes that control the cell cycle and promote apoptosis ${ }^{5,26}$. UV-induced mutations of the p53 gene not only abolish, but also stabilize the tumor suppressor activity of the 553 protein, resulting in its accumulation to levels that can be detectable immunohistochemically ${ }^{27}$. Activation of p53 induces the expression of several genes including the human homolog to the murine-double-minute gene (mdm)- $2^{17}$. One of the mechanisms to activate the p53 protein is the formation of a complex with the MDM2 protein. This bond interrupts its transcriptional activity while promoting its degradation and has been considered a mechanism for malignant transformation ${ }^{3,13}$.

It is known that carcinogenesis is frequently associated with protein expression, which allows for the identification 
of molecular alterations related to malignant transformation. In oral carcinogenesis, $\mathrm{p} 53$ and MDM2 proteins are involved in a complex manner, and other proteins, like p14 ${ }^{\mathrm{ARF}}$, are also engaged in these pathways. It may be clarified, when considered that $p 14 A R F$ interacts with the oncogenic protein MDM2, inducing stabilization of p53 and enhancing p53related functions ${ }^{13}$. Furthermore, concomitant immunopositivity for p14ARF and MDM2 overexpression was found in oral squamous cell carcinoma, whereas an inverse correlation between $\mathrm{p} 14 \mathrm{ARF}$ and MDM2 expression and diffuse staining of p53 were detected, showing that at least one protein was altered in most cases ${ }^{28}$.

In the literature, a great deal of cases regarding the expression of oncogenic proteins has been observed in oral squamous cell carcinoma. However, few studies have been referenced about the interaction of p53 and MDM2 in premalignant oral lesions with neoplasmic potential, such as actinic cheilitis. Thus, the aim of the present study was to evaluate, using immunohistochemical techniques, p53 and MDM2 protein expression in actinic cheilitis with different degrees of epithelial dysplasia, in order to provide information of a possible role of these biomarkers that can contribute to a better understanding of the malignant potential of this pathology.

\section{MATERIAL AND METHODS}

Fifty-eight cases of actinic cheilitis were selected for this study from the archives of the Aristides Maltez Cancer Hospital in Salvador, Bahia, Brazil. The histological sections for each case were stained by hematoxylin and eosin (HE) and subjected to morphological analysis under light microscopy. The histological degree of epithelial dysplasia was analyzed using the Bánoczy and Csiba ${ }^{4}$ (1976) parameters based on the epithelial alterations defined by the $\mathrm{WHO}^{24}$ (1997): presence of irregular epithelial stratification, hyperplasia of the basal layer, presence of rounded rete pegs, increased number of suprabasal mitoses, loss of basal layer cell polarity, increased nucleuscytoplasmic ratio, nuclear polymorphism and hyperchromatism, enlarged nucleoli, keratinization of single cells or cell groups in the prinkle layer, and loss of intercellular adhesion. The lesions were classified as mild, when two of these alterations were present; moderate, when three or four of the alterations were present, and severe when five or more of the above mentioned alterations were observed.

\section{Immunohistochemical Procedures}

The evaluation of p53 and MDM2 proteins was carried out by immunohistochemical analysis using the streptavidinbiotin method. Four-micrometer-thick tissue sections were obtained, deparaffinized and subjected to antigen recovery treatment. This was done by placing the slides, soaked in a citrate buffer target retrieval solution, $\mathrm{pH} 6.0$ at $97^{\circ} \mathrm{C}$, in a double boiler for $30 \mathrm{~min}$ for MDM2 and $10 \mathrm{~min}$ for p53. The primary monoclonal mouse p53 antibody (DO-7,
DAKO; 1:50 dilution) was incubated for $1 \mathrm{~h}$ and the monoclonal mouse MDM2 antibody (SMP14, DAKO; 1:40 dilution) for $16 \mathrm{~h}$ at room temperature. After incubating the primary antibodies, the sections were exposed to the streptavidin-biotin complex. The DO-7 anti-p53 antibody detects both mutant and wild-type p53. In order to develop the reaction, a $0.03 \%$ diaminobenzidine chromogenic solution was used with $1 \mathrm{~mL}$ of $\mathrm{H}_{2} \mathrm{O}_{2}$ for five min in a dark room. Then, counterstaining was carried out with Harris hematoxylin. As a positive control of the p53 protein, histological sections of squamous lip cell carcinoma were used and for the MDM2 protein sections of colon adenocarcinoma. The negative controls were obtained by substituting the primary antibody for a buffer solution. For assessing the immunostaining, the samples were analyzed by the mean percentage of positive cells determined from the percentage of total positive and negative cells derived from 10 random areas at $\times 400$ magnification and classified semi-quantitatively as described by Lu et al. (1999): ${ }^{18} 0(0 \%$ positive cells); +1 (<10\% positive cells); $+2(10-50 \%$ positive cells) $;+3$ ( $>50 \%$ positive cells). Furthermore, an immunostaining pattern was performed to classify epithelium compartment involvement (basal layer expression, suprabasal layer expression or both).

\section{Statistical Analysis}

The correlation between the expression of p53 and MDM2 proteins and the degree of epithelial dysplasia was carried out using the non-parametric Spearman rank correlation test. The mean values of cells testing positive for the p53 and MDM2 proteins were also compared in the different types of epithelial dysplasia using Student's t-test at $5 \%$ significance level.

\section{RESULTS}

\section{Histopathological Findings}

The sections from the 58 cases of actinic cheilitis were analyzed with a light microscope, revealing lesions lined with stratified squamous epithelium and varying degrees of keratinization, with a predominance of orthokeratinized epithelium. The lamina propria, represented by a narrow strip of dense conjunctive tissue, was vascularized and infiltrated by lymphoplasmacytic cells. Subjacent to this region, an extensive area of amorphous, basophilic material was observed, which was interpreted as solar elastosis.

According to the histological grading system used by Banóczy and Csiba ${ }^{4}$ (1976), 12 cases were classified as moderate epithelial dysplasia, and 46 cases as severe. Among the cases of epithelial dysplasia, the most common histological alterations observed were the loss of basal cell polarity and nuclear hyperchromatism $(93.1 \%)$ followed by nuclear polymorphism $(79.3 \%)$, and the occurrence of rounded or rounded rete pegs $(70.6 \%)$ (Figure 1).

\section{Immunohistochemical Analysis}

The immunohistochemical expression for the p53 
proteins was observed in all the cases of actinic cheilitis, with the nuclear staining pattern expressed in the basal and suprabasal layers. The positive nuclei for p53 showed an intense immunostaining in basal layer cells (Figure 2A), while in the suprabasal layer there was a predominance of slightly stained nuclei (Figure 2B). The labeling of the MDM2 protein was also observed in all cases, but with different intensities of nuclear staining and a predominance of a more discrete expression. Most cases (58\%) showed immunoreactivity to MDM2 in the basal layer only, and the remaining cases (42\%) showed immunoreactivity to MDM2 in both the basal and the suprabasal layers (Figure 3A). The positive cells in the suprabasal layer were sparsely distributed (Figure 3B). The sections analyzed showed only areas of actinic cheilitis.

In the semiquantitative analysis, the majority of cases was classified as $+3(>50 \%$ positive cells $)$ for the $\mathrm{p} 53(\mathrm{n}=51)$ and MDM2 $(\mathrm{n}=38)$ proteins. The cases classified as $+2(10-$ $50 \%$ positive cells) summed $12 \%$ for the $\mathrm{p} 53$ protein $(n=7)$ and $32 \%$ for the MDM2 protein $(n=19)$. No cases of actinic cheilitis were observed with less than $10 \%$ of the cells testing

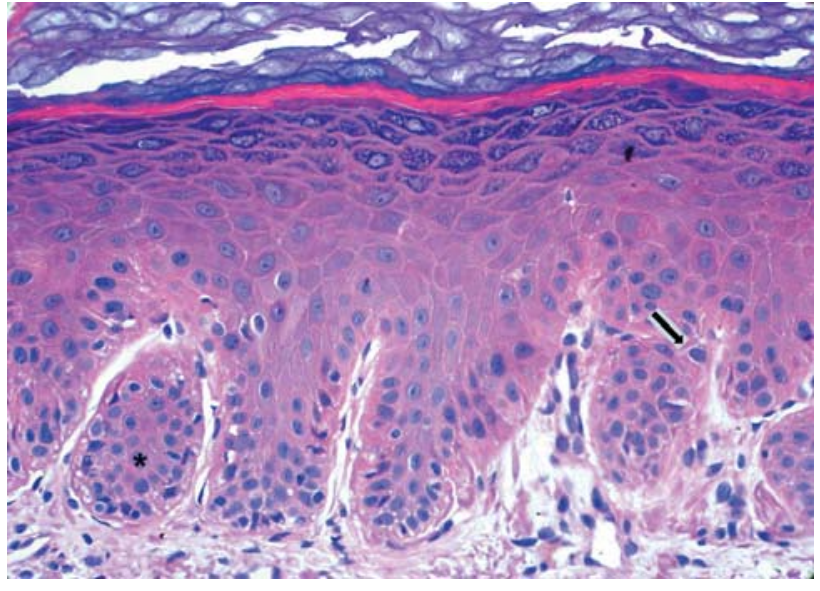

FIGURE 1- Severe epithelial dysplasia in actinic cheilitis. Nuclear hyperchromatism of basal cells (arrow), nuclear polymorphism and rounded rete pegs (asterisk). HE ×200
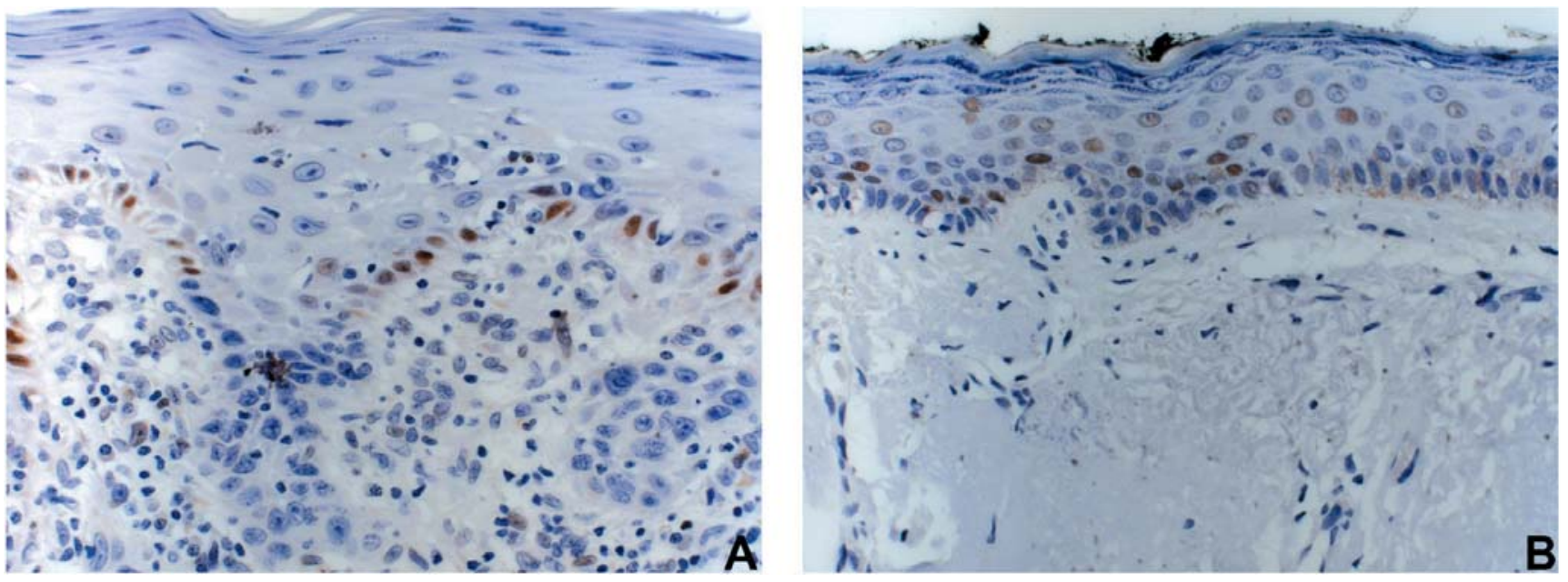

FIGURE 2- Mild and Moderate epithelial dysplasia in actinic cheilitis. Discrete p53 nuclear immunostaining only in basal layer cells (A); p53 nuclear immunostaining in suprabasal layer cells (B). Streptavidin-biotin $\sim \times 400$
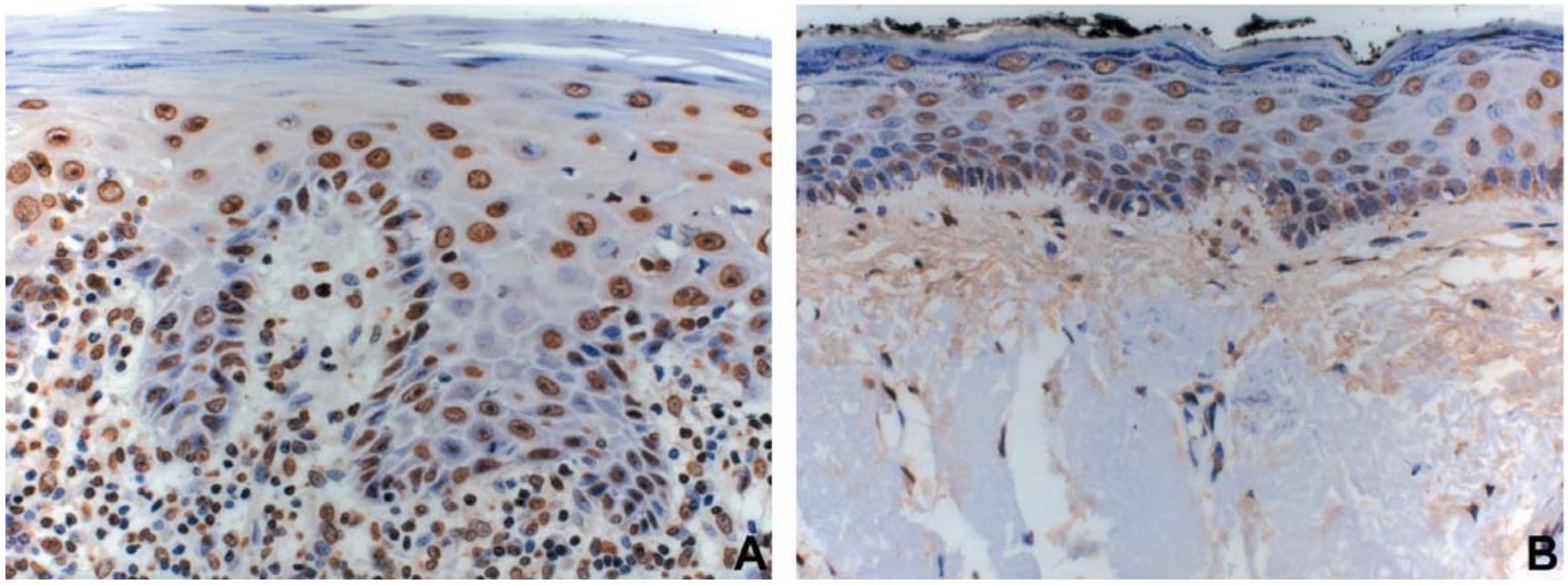

FIGURE 3- Mild and Moderate epithelial dysplasia in actinic cheilitis. Intense MDM2 nuclear immunostaining in all stratified epithelium cells (A); MDM2 nuclear immunostaining predominantly in suprabasal layer cells (B). Streptavidin-biotin $\sim \times 400$ 
positive for the $\mathrm{p} 53$ protein and only 1 case had a +1 score for the MDM2 protein.

No statistically significant difference was observed in the mean number of cells testing positive for the p53 and MDM2 proteins in the types of epithelial dysplasia studied (p53: $\mathrm{p}=0.099$; MDM2: $\mathrm{p}=0.378$, Chi-square). A statistically significant correlation was observed between the percentage of cells testing positive for the p53 and MDM2 proteins in the 58 cases of actinic cheilitis. This correlation was not dependent on the degree of epithelial dysplasia (Table 1). In this study, normal mucosa and areas exposed to the sun without the presence of actinic cheilitis were not analyzed. The objective was to compare the expression of both type of proteins, only in mucosa with actinic cheilitis.

TABLE 1- Correlation between p53 and MDM2 proteins in severe and moderate epithelial dysplasia

\begin{tabular}{lccc}
\hline $\begin{array}{l}\text { Epithelial } \\
\text { Dysplasia }\end{array}$ & $\mathbf{n}$ & $\begin{array}{c}\text { Correlation } \\
\text { (p53 and MDM2) }\end{array}$ & $\mathbf{p}$ \\
\hline Moderate & 12 & 0.67420 & $0.0162^{*}$ \\
Severe & 46 & 0.50620 & $0.003^{*}$ \\
Moderate & 58 & 0.53455 & $0.0001^{*}$ \\
+ severe & & & \\
\hline
\end{tabular}

*Significant level at 5\%. Spearman Test.

\section{DISCUSSION}

Alterations in the regulation of the different proteins involved in the cell cycle have already been observed in the earliest phases of oral cancer. Previous studies, $6,27,26,32$ confirmed that the expression of certain proteins, such as p53, can be significantly altered both in the cases of epithelial dysplasia as well as in oral squamous cell carcinomas. In the genesis of malignant lip lesions, the mutation and expression of the p53 protein can be associated with the action of specific carcinogens such as ultraviolet radiation ${ }^{6,16}$. In the literature, the studies on the expression of this protein, as well as its ability to aid in predicting the prognosis, have been carried out were carried out on different types of premalignant lesions. There are few specific studies on cases of actinic cheilitis. In the present study, p53 protein expression was confirmed in all cases of actinic cheilitis. These results were similar to those of Crosthwaite, et al. ${ }^{6}$ (1996), which that showed high expression levels in all cases of actinic cheilitis and skin keratosis. Other authors found different results in the levels of positive responses to this protein that ranged from 20 to $92 \%$ in different types of oral premalignant lesions ${ }^{14,27}$. Neto Pimentel, et al. ${ }^{23}$ (2006) found $85 \%$ of immunoreactivity to the $\mathrm{p} 53$ protein in actinic cheilitis and suggested that this lesion already have p53 gene abnormalities. These authors concluded that the percentage of stained nuclei for the p53 protein in the cheilitis and the presence of squamous cell carcinoma of the lip were not significantly associated, and questioned the role of a high immunoreactivity index as a marker of evolution into an invasive carcinoma.

Martinez, et al..$^{20}$ (2005) observed p53 high expression in normal lip mucosa exposed to solar radiation. This variability in the results is probably due to the diversity of the biochemical characteristics of p53 protein ${ }^{10}$, but the distinct premalignant lesions studied and the sensitivity of the immunohistochemical technique used should also be considered ${ }^{20}$. In this context, it can be inferred that mutation of gene p53 in lesions caused by the direct effects of ultraviolet light, represents an independent mechanism, different to oral leukoplasias in which smoking and alcohol consumption are considered determining factors. Once mutated, the p53 gene undergoes conformational and structural alterations that causes its deactivation and make it impossible to carry out its function. This deactivation leads to a greater stabilization that considerably increases its halflife, allowing for protein identification by immunohistochemical methods ${ }^{7,17}$. Although considered rare events, the presence of "nonsense" mutations or the deletion of both alleles of gene p53 prevents its translation due to the production of unstable proteins that interfere directly in its expression and detection ${ }^{30}$.

During the immunohistochemical analysis of the AC cases, we observed that $\mathrm{p} 53$ protein expression occurred in both basal and suprabasal layer epithelial cells. Equal immunolocalization has been obtained by other authors in different cases of premalignant oral lesions ${ }^{6,9,14,15,23}$, although Argawal, et al. ${ }^{2}$ (1998) observed that the p53 protein was only expressed in the nucleus of basal layer epithelial cells in cases of oral leukoplasias. It is implied that p53 protein expression in keratinocytes, and not in differentiated cells, supports the potential role of p53 in preventing early carcinogenesis $^{31}$. Therefore, alterations in gene p53 might be involved in initial events of oral carcinogenesis, occurring before coarse phenotypic alterations ${ }^{25}$. These outcomes have been emphasized by Tron, et al. ${ }^{31}$ (1998) and Martínez, et al. ${ }^{21}$ (2008), who found a significantly increased p53 expression in AC cases when compared to normal lip and oral mucosa. We consider p53 suprabasal expression in actinic cheilitis an advanced process in lip carcinogenesis. However, in the same way as other authors ${ }^{12,2}, 5$ we could not demonstrated that $\mathrm{p} 53$ protein presence is related to the degree of epithelial dysplasia.

Since the lip is a transition tissue between skin and oral mucosa, expression of p53-regulated genes in the lip could differ from both intraoral and skin malignancies, which has been shown by Martínez, et al. ${ }^{21}$ (2008) in the epithelial layers of AC lesions compared to normal lip, where both p53 and MDM-2 were significantly up-regulated. MDM2, when bonding to the p53 activation domain, inhibits its ability to stimulate transcription and also leads to its rapid degradation using the ubiquitin system ${ }^{22,30}$. In the present study, the expression of the MDM2 protein, one of the main negative regulators of the p53 protein, was also evaluated. The expression of MDM2 was observed in all the cases of actinic cheilitis presented herein, although with a lower expression intensity in relation to the $\mathrm{p} 53$ protein. This result 
differs from those obtained by Crosthwaite, et al. ${ }^{6}$ (1996), where $60 \%$ of the cases of epithelial dysplasias that expressed the MDM2 protein presented an intense degree of nuclear staining. We observed as well that the expression of the MDM2 protein occurred in both basal and suprabasal layers in $42 \%$ of the cases and in the basal layer only in $58 \%$ of the cases regardless the degree of epithelial dysplasia. However, Ganguli, et al. ${ }^{8}$ (2000) observed the expression of the MDM2 protein in premalignant skin lesions only in the nuclei of basal layer epithelial cells.

Yanamoto, et al. ${ }^{32}$ (2002) studied a significant number of oral squamous cell carcinoma and confirmed a correlation between the superexpression of the MDM2 protein and an unfavorable prognosis for the disease. Overexpression of MDM-2 has also been associated with increased malignancy ${ }^{1}$. Regarding actinic cheilitis, it was observed here that the superexpression of this protein occurred in both moderate and severe types of epithelial dysplasia, which have a higher risk for malignant transformation. Furthermore, the present study established a statistically significant correlation between the expression of p53 and MDM2 proteins in cases of actinic cheilitis. Similar results regarding the expression of these proteins were observed in oral leukoplasias as well as in oral squamous cell carcinoma $^{2,20}$. This factor probably demonstrates that the MDM2 protein is involved in the accumulation of the p53 protein in oral carcinogenesis and especially in the genesis of lip cancer. Likewise, Martínez, et al. ${ }^{21}$ (2008) considered increased p53 expression as a predictor of premalignancy in the lip, suggesting that its detection may be a valuable tool in AC diagnosis.

\section{CONCLUSIONS}

In conclusion, the results showed a high percentage of immunostaining, both for $\mathrm{p} 53$ and for MDM2 in cases of $\mathrm{AC}$, which suggest a possible role of these biomarkers in lip carcinogenesis, independent of the disease stage. Furthermore, a significant correlation was observed in the expression of these proteins, regardless the epithelial dysplasia degree, which demonstrates an aggressive state for this lesion.

\section{REFERENCES}

1- Agarwal S, Mathur M, Srivastava A, Ralhan R. MDM2/p53 coexpression in oral premalignant and malignant lesions: potential prognostic implications. Oral Oncol. 1999;35:209-16.

2- Agarwal ML, Taylor WR, Chernov MV, Chernova OB, Stark GR. The p53 network. J Biol Chem. 1998;273(1):1-4.

3- Araújo VC, Martins MT, Leite KR, Gomes RS, Araújo NS. Immunohistochemical MDM2 expression in minor salivary gland tumours and its relationship to p53 gen status. Oral Oncol. 2000;36(1):67-9.

4- Banczy J, Csiba A. Occurrence of epithelial dysplasia in oral leukoplakia. Oral Surg. 1976;42(6):766-74.
5- Colman MS, Afshari CA, Barret JC. Regulation of p53 and activity in response to genotoxi stress. Mutat Res. 2000;462(2-3):179-88.

6- Crosthwaite N, Teale D, Franklin C, Foster GA, Stringer BM. p53 protein expression in malignant, pre-malignant and non- malignant lesions of the lip. J Clin Pathol. 1996;49(8):648-53.

7- Field JK, Pavelic ZP, Spandidos DA, Stambrook PJ, Jones AS, Gluckman JL. The role of the p53 tumor suppressor gene in squamous cell carcinoma of heas and neck. Arch Otolaryngol Head Neck Surg. 1993;119(10):1118-22.

8- Ganguli G, Abecassis J, Wasylyk B. MDM2 induces hyperplasia and premalignant when expressed in the basal layer of the epidermis. EMBO J. 2000;19(19):5135-47.

9- Gomes APN, Araújo VC, Pinto Jr DS. Avaliação imuno-histoquímica de p53 e PCNA como marcadores de risco para lesões bucais potencialmente malignas. RPG Rev Pós Grad. 2000;7(4):349-55.

10- Hall PA, Lane DP. p53 in tumor pathology: can we trust immunohistichemistry? Revisited! J Pathol. 1994;172(1):1-4.

11- Kaugars GE, Pillion T, Svirsky JA, Page DG, Burns JC, Abbey LM. Actinic cheilitis: a review of 152 cases. Oral Surg Oral Med Oral Pathol Oral Radiol Endod. 1999;88(2):181-6.

12- Kerdpon D, Rich AM, Reade PC. Expression of p53 in oral mucosal hyperplasia, dysplasia and squamous cell carcinoma. Oral Dis. 1997;3(2):86-92.

13- Kresty LA, Mallery SR, Knobloch TJ, Song H, Lloyd M, Casto BC, et al. Alterations of p16INK4a and p14ARF in patients with severe oral epithelial dysplasia. Cancer Research. 2002;62(18):5295-300.

14- Kusama K, Okutsu S, Takeda A, Himiya A, Kidokoro Y, Chu L, et al. p53 gene alterations and p53 protein in oral epithelial dysplasia and squamous cell carcinoma. J Pathol. 1996;178(4):415-21.

15- Lawall MA, Crivelini MM. PCNA and p53 expression in oral leukoplakia with different degrees of keratinization. J Appl Oral Sci. 2006;14(4):276-80.

16- Lee YS, Teh M. p53 expression in pseudoepitheliomatous hyperplasia, keratoacanthoma, and squamous cell carcinoma of skin. Cancer. 1994;73(9):2317-23.

17- Levine AJ, Perry ME, Chang A, Silver A, Dittmer D, Wu M, et al. The 1993 Walter Hubert Lecture: the role of p53 tumour suppressor gene in tumorigenesis. Br J Cancer. 1994;69(3):409-16.

18- Lu S, Tiekso J, Hietanen S, Syrjänen K, Havu VK, Syrjänen S. Expression of cell-cycle protein p3, p21 (WAF-1), PCNA and Ki-67 in benign, premalignant skin lesions with implicated HPV involvement. Acta Derm Venereol. 1999;79:268-73.

19- Markopoulos A, Albanidou-Farmaki E, Kayavis I. Actinic cheilitis: clinical and pathologic characteristics in 65 cases. Oral Dis. 2004;10(4):212-6.

20- Martínez A, Brethauer U, Rojas IG, Spencer M, Mucientes F, Borlando $\mathrm{J}$, et al. Expression of apoptotic and cell proliferation regulatory proteins in actinic cheilitis. J Oral Pathol Med. 2005;34(5):257-62.

21- Martínez A, Brethauer U, Borlando J, Spencer ML, Rojas IG. Epithelial expression of $\mathrm{p} 53, \mathrm{mdm}-2$ and $\mathrm{p} 21$ in normal lip and actinic cheilitis. Oral Oncol. 2008; 44(9):878-83.

22- May P, May E. Twenty years of p53 research: structural and functional aspects of the p53 protein. Oncogene. 1999;18(53):7621-36. 
23- Pimentel DR Neto, Michalany N, Alchorne M, Abreu M, Borra RC, Weckx L. Actinic cheilitis: histopathology and p53. J Cutan Pathol. 2006;33(8):539-44.

24- Pindborg JJ, Reichart PA, Smith CJ, van der Waal. Histological Typing of Cancer and Precancer of the Oral Mucosa. WHO International Classification of tumours. Berlin Heidelberg: Springer Verlag; 1997.

25- Regezi JA, Zarbo JR, Regev E, Pisanty S, Silverman S, Gazati D. p53 protein expression in sequential biopsies of oral dysplasias and in situ carcinomas. J Oral Pathol Med. 1995;24(1):18-22.

26- [de] Rosa I, Staibano S, Lo Muzio L, Delfino M, Lucariello A, Coppola A, de Rosa G, Scully C. Potentially malignant and malignant lesions of the lip. Role of silver staining nucleolar organizer regions, proliferation cell nuclear antigen, p53, and c-myc in differentiation and prognosis. $\mathrm{J}$ Oral Pathol Med. 1999;28(6):252-8.

27- Rowley H, Helliwell TR, Jones AS, Roland NJ, Field EA, Field JK. An immunohistochemical analysis of p53 protein expression in premalignant and malignant tissues of the oral cavity. Clin Otolaryngol Allied Sci. 1997;22(1):23-9.

28- Sano T, Hikino T, Xue Q, Saito T, Kashiwabara K, Oyama T, et al. Immunohistochemical inactivation of p14ARF concomitant with MDM2 overexpression inversely correlates with p53 overexpression in oral squamous cell carcinoma. Pathol Int. 2000;50(9):709-16.

29- Santos JN, Sousa SOM, Nunes FD, Sotto, MN, Araújo, VC. Altered cytokeratin expression in actinic cheilitis. J Cutan Pathol 2003;30(4):23741 .

30- Soussi T, Legros Y, Lubin R, Ory K, Schlichtholz B. Multifactorial analysis of p53 alteration in human cancer: a review. Int $\mathrm{J}$ Cancer. 1994;57(1):1-9.

31- Tron VA, Trotter MJ, Tang L, et al. p53-regulated apoptosis is differentiation dependent in ultraviolet B-irradiated mouse keratinocytes. Am J Pathol 1998;153:579-85.

32- Yanamoto S, Kawasaki G, Yoshitomi I, Mizuno A. p53, mdm2, and p21 expression in oral squamous cell carcinomas: Relationship with clinicopathologic factors. Oral Surg Oral Med Oral Pathol Oral Radiol Endod. 2002;94(5):593-600 